\title{
Physico-chemical Properties of Milk and Dairy Products Collected from Allahabad City, India
}

\author{
Nivedita Prasad $^{1 *}$, Sangeeta Shukla $^{1}$ and P.W. Ramteke ${ }^{2}$ \\ ${ }^{1}$ Department of Dairy Microbiology, ${ }^{2}$ Department of Biological Sciences, SHUATS, \\ Allahabad, India \\ * Corresponding email
}

\begin{tabular}{|c|c|}
\hline & A B S T R A C T \\
\hline $\begin{array}{l}\text { K e y w o r d s } \\
\text { Buffalo milk, Cow } \\
\text { milk, Curd, Goat milk, } \\
\text { Paneer, Physico- } \\
\text { chemical }\end{array}$ & \multirow{3}{*}{$\begin{array}{l}\text { Samples of milk from buffalo, cow, goat milk, samples of dairy products from } \\
\text { paneer and curd were used for analysis of physico-chemical parameters viz fat, } \\
\text { protein, moisture, ash, T.S., S.N.F. and lactose. Maximum fat percentage among } \\
\text { milk product samples was observed in paneer which ranged } 14.67 \pm 0.421 \text { followed } \\
\text { by cow milk } 6.421 \pm 0.0 .107 \text {. The maximum protein percentage was observed in } \\
\text { paneer } 12.978 \pm 0.244 \text {. Moisture content among milk samples was observed highest } \\
\text { in goat milk } 92.421 \pm 0.082 \text {. Maximum lactose content among milk samples was } \\
\text { found in buffalo milk } 5.636 \pm 0.011 \text { while minimum ash percentage was found in } \\
\text { cow milk } 0.692 \pm 0.007 \text {. }\end{array}$} \\
\hline Article Info & \\
\hline $\begin{array}{l}\text { Accepted: } \\
\text { 10 June } 2018 \\
\text { Available Online: } \\
\text { 10 July } 2018\end{array}$ & \\
\hline
\end{tabular}

\section{Introduction}

Milk and dairy products are part of a healthy diet which, besides cow's milk, sheep's, goats and buffalo's milk are involved (Hinrichs, 2004). Milk is a complex colloidal dispersion containing fat globules, casei micelles and whey proteins in an aqueous solution of lactose, minerals and a few other minor compounds. Its physical and chemical properties depend on intrinsic compositional and structural factors, extrinsic factors such as temperature and post-milking treatments. An understanding of these properties is important in the technological and engineering design and operation of milk processes and processing equipment, the design of modern methods of milk analysis, the determination of milk microstructures and the elucidation of complex chemical reactions that occur in milk.

Measurement of some of the physico-chemical properties is used to assess milk quality. Milk is an important source of all basic nutrients required for mammals including human beings. Milk from various mammals such as cow, buffalo, goat, sheep, camel, etc. is used for different nutritional purposes, e.g., feeding to young ones and preparation of some nutritional products such as milk cream, butter, yogurt, ghee, sour milk, etc. (Webb et al., 1974; Hassan, 2005). Nutritionally 
enriched milk and its products with enhanced biological potential and without health risks are generally demanded (Khan and Zeb, 2007; Baloch et al., 2006). The major chemical components of milk include water, fats, proteins, carbohydrates, minerals, organic acids, enzymes and vitamins.

The best buffaloes of the world are found in the Indian subcontinent, and India is the leading buffalo country, which produces 96 million tons of milk annually. Buffalo milk $(\mathrm{BM})$ is ranked second after cow milk $(\mathrm{CM})$ in the world as the BM produced is more than $12 \%$ of the world's milk production. About $70 \%$ of the total $\mathrm{BM}$ is produced by India. World milk production has doubled in the last decade, with BM production ranking second after bovine milk. Various compositional and functional properties render the BM eminently suitable for manufacture of dairy products such as ultra-high temperature (UHT) cream, dried ice cream mixes, dairy whiteners, edible casein, and caseinates. However, from a technological point of view, BM is often not considered an ideal fluid for manufacture of several types of cheeses, milkpowders, evaporated and condensed milk, and infant formulas (Khedkar et al., 2016)

Buffaloes are the second largest source of milk supply in the world. InIndia, nearly half of the milk processed by the organized dairies comes from buffaloes. The BM is richer in fat than milk from cattle. Generally, it has also higher levels of proteins, lactose, and ash, although these differences are not as high in fat.

Goat's milk contains vitamins, minerals, trace elements, electrolytes, enzymes, proteins, and fatty acids that are easily assimilated by the body. Goat's milk has a similarity to human milk that is unmatched in cow milk and also has several medicinal values (Kumar et al., 2012).
Dahi is a fermented dairy product of major importance in Indian subcontinent. Since time immemorial it is being used for its nutritive and therapeutic values (Aneja et al., 2002). The chemical composition of curd has been reported as fat content ranging from 5-8 \%, protein $3.3-3.4 \%$, lactose 3.5 to 4.5 and $0.5-$ $1.1 \%$ lactic acidity.

Paneeris non-fermentative, non-rennet, nonmelting and unripened type of cheese similar to the white cheese (Chandan, 2007). According to the FSSAI (2011), Paneershall not contain more than 70.0 per cent moisture and the milk fat content shall not be less than 50.0 per cent of the dry matter.

The physico-chemical properties of milk fat show some natural variations depending upon factors like method of manufacture, age and condition of the sample, species, breed, individuality of animal, stage of lactation, number of lactation (age of animal), season of the year, region of the country, feed of theanimal etc. (De, 2005; Aneja et al., 2002). The focus of the present study is to highlight the comparative study of the detailed composition and properties of buffalo, cow, goat milk and dairy products like curd and paneer collected from different regions of Allahabad city.

\section{Materials and Methods}

The present investigation was undertaken at Department of Dairy Microbiology, SHUATS, Allahabad during 2015-16 and 2017-18 to physico-chemical properties of milk and dairy products collected from Allahabad city. The experiment was laid out in completely randomized design replicated thrice.

\section{Sample collection}

Fresh buffalo, cow and goat milk samples were collected from different regions of 
Allahabad city. Also, fresh dahi and paneer samples were collected from the vendors/shopkeepers and were brought to the University campus in ice box. It was ensured that the temperature variation was not remarkable in the product.

Three samples from each location were collected. The samples were analyzed in the laboratory of the Department of Food Engineering, SHUATS, Allahabad.

\section{Physico-Chemical analysis}

For moisture content $5 \mathrm{~g}$ (Mo) of the milk was placed in petri dishes and kept in the Gallenkamp oven at $130^{\circ} \mathrm{C}$ for $1 \mathrm{~h}$. The dried samples were then cooled in a desiccator and weighed (M1). The average mass of the three masses was used to calculate the moisture content of the samples. The moisture content expressed as a percentage was calculated as follows:

Moisture content (\%) 1/4 Mo_M1/Mo_100 (AOAC, 2000).

Chemical composition Total solids content was determined by gravimetric method, Kjeldahl technique was utilized to estimate the protein content, Gerber method was employed to determine the lipid content whereas, ash content was quantified using muffle furnace at $550^{\circ} \mathrm{C}(\mathrm{AOAC}, 2012)$.

The aforementioned analyses were performed in triplicate on the final products.

\section{Statistical analysis}

Results were expressed as mean $\pm S D$ of three separate determinations. The significant differences between means were calculated by a one-way analysis of variance (ANOVA) using Duncan's multiple-range test at $P<0.05$.

\section{Results and Discussion}

Samples of milk from buffalo, cow, goat milk and of dairy products paneer and curd were used for analysis of physicochemical parameters viz fat, protein, moisture, ash, T.S., S.N.F. and lactose. The various physicalchemical parameters of milk and milk products are presented in table 1 .

\section{Physico-chemical properties of raw milk}

In the present study, the mean fat content in buffalo, cow and goat milk was reported $6.421 \pm 0.0 .107,4.06 \pm 0.007$ and $3.599 \pm 0.084$ respectively which showed that highest fat $\%$ is present in buffalo milk as compared to cow and goat milk. Similar findings were reported by Dubey et al., (1997) (6.80), Sodi et al., (2008) $(7.7 \pm 1.0)$ fat\% in buffalo milk. Misra et al., 2008 conducted study on different breeds of Indian buffaloes and reported the highest fat\% in Murrah (7.53 \pm 0.19$)$ and lowest fat\% in Surti $(6.17 \pm 0.02)$. Similarly highest protein\% was found in buffalo milk ie., 3.85 \pm 0.01 than to cow and goat milk which is very much in accordance with the finding of Patino and Stefani 2005. The total solid content of buffalo's milk being 10.921 $\%$, was markedly higher than that of cow milk $(8.528 \%)$. Lactose is also known as milk sugar and is composed of galactose and glucose. Among all the tested milk samples, the buffalo milk contained the highest amount of lactose. These results were in agreement with those reported by Spanghero and Susmel (1996) and Ahmed et al., (2008). In goat milk the content of carbohydrate was in range of $4.35 \pm 0.105$, fat $3.599 \pm 0.084$, protein $3.258 \pm 0.009$, moisture $92.421 \pm 0.082$ and S.N.F. 3.974 \pm 0.010 . Similar findings were also reported by Hamad and Baiomy (2008) and Imran et al., (2010). The statistical analysis showed insignificant difference. 
Physico-chemical properties of milk products

The maximum fat, protein, ash, T.S., S.N.F. and lactose content among milk product samples was observed in paneerbut less moisture as compared to curd. The protein and fat $\%$ observed in paneer was $12.978 \pm 0.244$ and $20.67 \pm 0.421$ respectively. In curd the values recorded for protein was $2.881 \pm 0.110$, fat $(2.536 \pm 0.105)$ and T.S. $(6.154 \pm 0.148)$. Similar results were presented by Obi and Ikenebomeh (2007); Younus et al., (2002) and El-Bakri and El-Zubeir (2009).

In conclusion among the milk products studied Paneer contained higher fat, protein, ash, T.S. and S.N.F contents and less moisture and carbohydrate content than curd.. Buffaloes are the second largest source of milk supply in the world. In India, nearly half of the milk processed by the organized dairies comes from buffaloes. The BM is richer in fat than milk from cattle. Generally, it has also higher levels of proteins, lactose, and ash, although these differences are not as high in fat.

\section{Acknowledgements}

The first author acknowledges the Institute fellowship from Maulana Azad National Fellowship and infrastructural facilities received from the Department of Dairy Microbiology, SHUATS, Allahabad.

\section{References}

Abd El-Salam, M.H. and El-Shibiny, S., 1966. The chemical composition of buffalo milk. I. General composition. Indian J. Dairy Sci., 19: 151-154.

Ahmad, S., Gaucher, I., Rousseau, F., Beaucher, E., Piot, M., Grongnet, J.F. and Gaucheron, F., 2008. Effects of acidification on physico-chemical characteristics of buffalo milk: A comparison with cow's milk. FoodChem. 106: 11-17.

AOAC, 2000. Official Methods of Analysis International, 17th Ed. AOAC, Washington, DC.

Dubey, P.C., Suman, C.L., Sanyal, M.K., Pandey, H.S., Saxena, M.M. and Yadav, P.L., 1997. Factors affecting the composition of milk of buffaloes. Indian J. Anim. Sci. 67:802-804.

El-Bakri J.M. and El-Zubeir I.E.M., 2009. Chemical and microbiological evaluation of plain and fruit yoghurt in Khartoum State, Sudan. Int. J. Dairy Tech., 4: 1-7.

Hamad, M. N. E. and Baiomy, A.A, 2010.Physical properties and chemical composition of cow's and buffalo's milk in Qena governorate. J. Food and Dairy Sci. 1(7): 397-403.

Imran, M., Khan, H., Hassan, S.S. and Rasool Khan, R., 2008.Physicochemical characteristics of various milk samples available in Pakistan.J. Zhejiang Univ. Sci. B. 9(7): 546-551.

Khedkar, C.D., Kalyankar, S.D. and Deosarkar, S.S., 2016. Buffalo Milk. In: Caballero, B., Finglas, P., and Toldrá, F. (eds.) The Encyclopedia of Food and Health. vol. 1, pp. 522-528. Oxford: Academic Press.

Obi, C.N. and Ikenebomeh, M.J., 2007. Studies on the microbiology and nutritional qualities of a Nigerian fermented milk product (Nono). Int. J. Dairy Sci. 2(1): 95-99.

Misra, S.S., Sharma, A., Bhattacharya, T.K., Kumar, P. and Saha, R.S., 2008. Association of breed and polymorphism of $\alpha$-s1 and $\alpha$-s2casein genes with milk quality and daily milk and constituent yield traits of buffaloes (Bubalus bubalis). Buffalo Bull. 27:294-301. 
Salunkhe, D.D., Chavan, K.D. and Sorte, G.D., 2008. Studies on the chemical and sensory quality of dahi sold in Nagpur city. J. Dairying, Foods \& H.S., 27 (3/4): 186-189.

Spanghero, M. and Susmel, P., 1996.Chemical composition and energy content of buffalo milk. $J$. Dairy Res. 63, 629-633.
Sodi, S.S., Mehra, M.L., Jain, A.K., Trehan, P.K., 2008. Effect of non-genetic factors on the composition of milk of Murrah buffaloes. Indian Vet. J. 85: 950-952.

Younus, S., Masud, T. and Aziz, T., 2002. Quality Evaluation of Market Dahi/Yoghurt. Pakistan J. Nutrition, 1: 226-230.

\section{How to cite this article:}

Nivedita Prasad, Sangeeta Shukla and Ramteke, P.W. 2018. Physico-chemical Properties of Milk and Dairy Products Collected from Allahabad City, India. Int.J.Curr.Microbiol.App.Sci. 7(07): 1662-1666. doi: https://doi.org/10.20546/ijcmas.2018.707.195 